\title{
Are Pandemics A Threat To Businesses? Lessons from Covid-19 Pandemic; a Case of Banking Sector in Kenya
}

\author{
Samuel Machiri Ndungu* \\ Kenya \\ *Corresponding Author: Samuel Machiri Ndungu, Kenya
}

\section{INTRODUCTION}

In the history of the past centuries, the world has experienced a series of pandemics ranging from different infectious diseases which have resulted in total drawback of the various sectors of development in the world and millions of deaths.The Coronavirus (SARS-CoV-2) outbreak, dubbed COVID-19is first and foremost, a human tragedy, affecting millions of people globally. The contagious Coronavirus, which broke out towards the end 2019, has led to a medical emergency across the world, with the World Health Organization officially declaring the novel Coronavirus a pandemic on March 11, 2020. Fears surrounding the impact of COVID-19 have significantly impacted the global economy, with key stock markets across the world losing 20-50\% of their value for the year-to-date. Many economists and institutions have cut their forecasts, with many experts predicting the potential onset of recessionary environments (Topcu, \&Gulal, 2020).

Historically, Influenza Spanish flu pandemic stands as the most ever deadly phenomenon that almost brought the world economy into it is kneels. According to Johnson and Mueller (2002) a total of 50 million succumbed to death from the pandemic, however other authors suggest that this could be an underestimation and that the true death toll was as high as 100 million. The pandemic affected several economic factors such as the banking sector, agricultural sector, education sector, and several operations were impacted all over the world. For the period of the last one hundred years, various pandemics have been experienced globally. However, the recent COVID-19 Pandemic has been considered as a similar reflection of what took place in the last one hundred years (The Spanish Flu of 1918 - 1920).

In the onset of the influenza pandemic, a number of near simultaneous events would likely occur. Not surprisingly, there would be a significant increase in demand for medical services among other myriad lifestyle changes. Depending on the severity of the outbreak, there would likely be a substantial decrease in demand for hotel, restaurant, and mass transportation services, as well as lower attendance at public events and a decline in retail shopping, as individuals (by choice or by force) seek to decrease their risk of infection. The supply of workers would temporarily decline as many became ill or stayed home to care for infected family members or school-restricted children. This reduction in the workforce would impair business functions, erode business revenues, and, not the least, adversely affect many household incomes. Revenue lost from the likely suspension of tourism in many countries and possible restrictions on trade could play an important economic role as well, meaning what starts as largely a healthy crisis quickly mutates into a financial and social crisis(Ashraf, 2020; Ozili, \&Arun, 2020).

Since the break out of the COVID-19 pandemic in late 2019 in Wuhan China, the disease has spread to almost all parts of the world without sparing anyone. Several industries ranging from air travel, agricultural, education, tourist, entertainment etc. have been hit hard by the COVID-19 pandemic to an extent that would take several years before they recover. According to the World Bank (2020), the COVID-19 pandemic has spread with alarming speed, infecting millions and bringing economic activity to a near-standstill as countries imposed tight restrictions on movement to halt the spread of the virus. As the health and human death toll grows, the economic damage is already evident and represents the largest economic shock the world has experienced in decades. The June 2020 Global Economic Prospects describes both the immediate and near-term outlook for the impact of the 
pandemic and the long-term damage it has dealt to prospects for growth ( $\mathrm{Zhang}, \mathrm{Hu}, \& \mathrm{Ji}, 2020$ ). The baseline forecast envisions a 5.2 percent contraction in global GDP in 2020, using market exchange rate weights - the deepest global recession in decades, despite the extraordinary efforts of governments to counter the downturn with fiscal and monetary policy support. Over the longer horizon, the deep recessions triggered by the pandemic are expected to leave lasting scars through lower investment, an erosion of human capital through lost work and schooling, and fragmentation of global trade and supply linkages.

Locally, the Kenyan economy has been devastated by the pandemic as witnessed in the performance of the stock \& financial markets, disruption of global supply chains, volatility of the Kenyan currency, reduction in diaspora remittances, and revision of monetary and fiscal policies.Basically, the banking sector specifically in Kenya is currently operating under serious risks (Wanjala, 2020). A glance at the trend of the NSE - 20 share index show a downward spike from a high of 2,000 to a low of 1,960 as at June 2020.

A similar conclusion can be arrived by analyzing the performance of a sample of performance of stocks of blue chip companies since the beginning of the year.

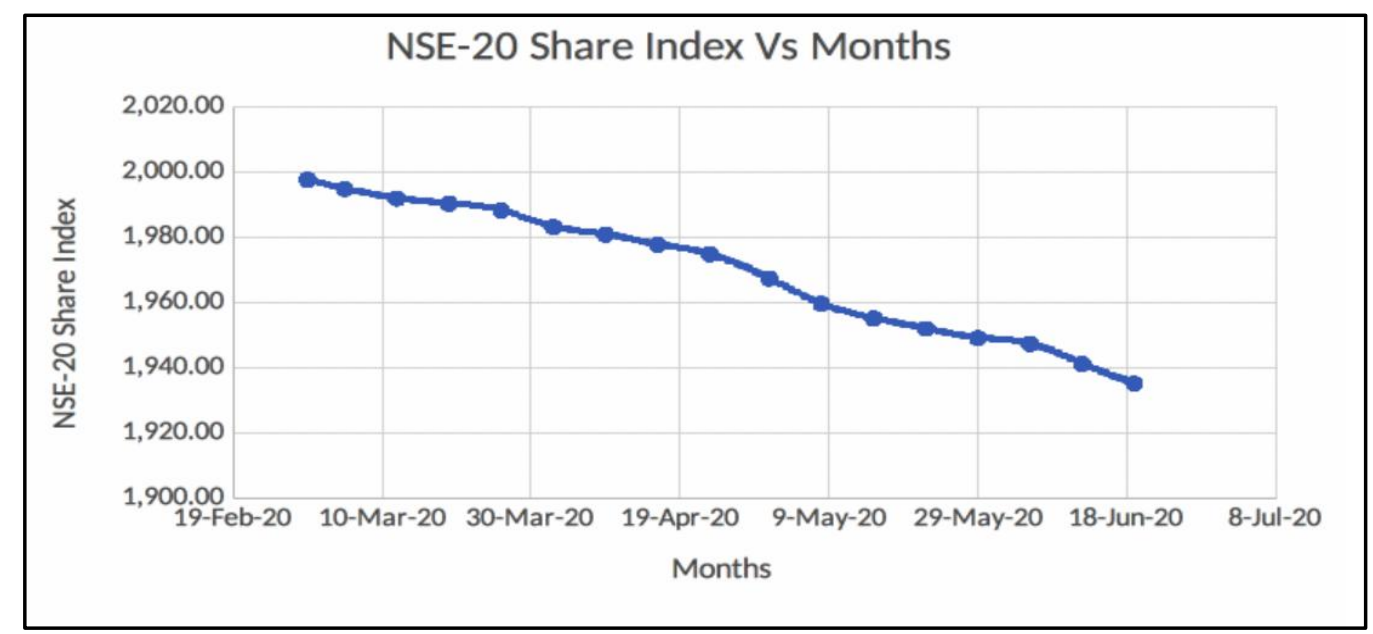

Performance of NSE-20 Share Index February to June 2020

Source: Nairobi Securities Exchange (2020)

\begin{tabular}{|r|l|c|c|c|}
\hline$\#$ & Company & $\begin{array}{l}\text { Prices as at 31st Dec 2019 } \\
\text { (Kshs) }\end{array}$ & $\begin{array}{l}\text { Prices at 1st Oct 2020 } \\
\text { (Kshs) }\end{array}$ & $\begin{array}{l}\text { YTD } \\
\text { Performance }\end{array}$ \\
\hline 1 & Bamburi Cement Ltd & 80.0 & 23.7 & $-70.38 \%$ \\
\hline 2 & Safaricom PLC & 31.5 & 29.8 & $-5.40 \%$ \\
\hline 3 & Equity Group Holdings PLC & 53.5 & 36.5 & $-31.78 \%$ \\
\hline 4 & KCB Group PLC & 54.0 & 39.1 & $-27.59 \%$ \\
\hline 5 & East African Breweries Ltd & 198.5 & 163.3 & $-17.76 \%$ \\
\hline 6 & $\begin{array}{l}\text { British American Tobacco } \\
\text { Kenya PLC }\end{array}$ & 500.0 & 348.3 & $-30.35 \%$ \\
\hline 7 & Diamond Trust Bank Kenya Ltd & 109.0 & 61.8 & $-43.35 \%$ \\
\hline 8 & $\begin{array}{l}\text { The Co-operative Bank of } \\
\text { Kenya Ltd }\end{array}$ & 16.4 & 11.8 & $-27.83 \%$ \\
\hline 9 & ABSA Kenya PLC & 13.4 & 9.8 & $-26.44 \%$ \\
\hline & & Average & $\mathbf{- 3 1 . 2 1 \%}$ \\
\hline
\end{tabular}

Performance of select Stocks from Nairobi Security Exchange

Source: Nairobi Securities Exchange (2020)

As the effect of the COVID-19 continues to be felt globally, the banking sector like any other sector has continued to face unpredictable uncertainty. The current environment being operated by the banking sector presents particular challenges and disruptions to the banks as a preferred store and creation of the wealth through the stock market. A preview of the performance of Bank Stocks at the NSE paint a grim picture as captured below. 
Are Pandemics A Threat To Businesses? Lessons from Covid-19 Pandemic; a Case of Banking Sector in Kenya

\begin{tabular}{|r|l|c|c|c|}
\hline$\#$ & Company & $\begin{array}{l}\text { Prices as at 31st Dec 2019 } \\
\text { (Kshs) }\end{array}$ & $\begin{array}{l}\text { Prices at 1st Oct 2020 } \\
\text { (Kshs) }\end{array}$ & $\begin{array}{l}\text { YTD } \\
\text { Performance }\end{array}$ \\
\hline 1 & Equity Group Holdings PLC & 53.50 & 36.50 & $-31.78 \%$ \\
\hline 2 & KCB Group PLC & 54.00 & 39.10 & $-27.59 \%$ \\
\hline 3 & Diamond Trust Bank Kenya Ltd & 109.00 & 61.75 & $-43.35 \%$ \\
\hline 4 & $\begin{array}{l}\text { The Co-operative Bank of } \\
\text { Kenya Ltd }\end{array}$ & 16.35 & 11.80 & $-27.83 \%$ \\
\hline 5 & ABSA Kenya PLC & 13.35 & 9.82 & $-26.44 \%$ \\
\hline 6 & HF Group Ltd & 6.46 & 3.97 & $-38.54 \%$ \\
\hline 7 & \& M Holdings Plc & 54.00 & 43.40 & $-19.63 \%$ \\
\hline 8 & NCBA Group Plc & 36.85 & 23.05 & $-37.45 \%$ \\
\hline 9 & Stanbic Holdings Plc & 109.25 & 80.00 & $-26.77 \%$ \\
\hline 10 & Standard Chartered Bank & 202.50 & 160.00 & $-20.99 \%$ \\
\hline & & & Average & $-30.04 \%$ \\
\hline
\end{tabular}

Performance of Bank Stocks at the NSE

Source: Nairobi Securities Exchange (2020)

In addition, Banks have had other disruptions like reduced operational hours due to restrictions intracounty movements and the dusk to dawn curfew; reduced physical interactions with customers in compliance with the Ministry of Health protocols; reduced non-funded incomes occasioned by suspension of transactional charges for small-amount transactions as sanctioned by the Central Bank of Kenya (CBK) as a way of minimizing physical handling of cash and a slow-down in economic activities greatly undermining the velocity of the movement of goods and services; suspension of debt servicing (debt moratorium measures and personal relief) has led most banks to tighten their risk appetite further denting the expansion of private credit. The freeze on credit specifically might lead to death of most Micro and Small Enterprises (MSME) further exacerbating the impact of the pandemic.

Moreover, the ongoing COVID-19 pandemic has put the global banking sector Kenya included under operational and liquidity risks. This has been facilitated by the introduced remote method of operation in the banking sector. This method puts the banking sector at risk of cyber-security issues. This is because of significantly higher levels of remote access to data and core systems, and because employees and management could be more susceptible to social engineering efforts in the midst of a crisis such as the current times of COVID-19 pandemic.

Likewise, an immense workforce challenge has hit the banking sector due to the current experienced regulations aimed at mitigating the spread of the COVID-19 pandemic. The restrictions put in place by the banking institutions to restrict some employees from accessing some physical facilities have brought out frustration in the employee workforce. Some employees do not have appropriate physical environments for remote working, or that their supervision and review processes arenot adequate in those situations. In some cases, there are no enough qualified employees to do the work that has to be done. As the economic fallout spreads, retail banks find themselves juggling some big priorities that require concrete steps to reposition now while also recalibrating for the future. Most Banks are working to keep their distribution channels open, despite social distancing advice and supervisory and compliance functions that were never designed for remote working. Banks are trying to manage revenue and customer expectations, despite near-zero interest rates and growing pressure on consumers.

\section{Statement of The Problem}

In Kenya, the banking sector serves as a key institution of the country's economic backbone that ensures the continuity in operation and development of other sectors. However, since 13 March 2020, the banking sector has been experiencing massive destruction through the performance of the financial market, the volatility of the Kenyan currency, reduction in diaspora remittances, and reversal of prior monetary and fiscal policies. According to Karunga (2020), Since the first Coronavirus case was reported in Kenya on $12^{\text {th }}$ of Match 2020, Most of the foreign investors who had invested in Kenya securities in the Nairobi Stock Exchange, begun disposing of their securities in fear of market 
collapse, a condition that led to a huge slump of the securities prices traded at the Exchange. From the statistics by (Odhiambo, 2020), The value of the NSE-20 Share Index has been established to be losing its value decreasing by 300 basis points between date $15^{\text {th }}$ of match 2020 and date $15^{\text {th }}$ of May 2020. Moreover, the performance of the major banking institutions that are part of the Blue-Chip companies on the exchange as of $15^{\text {th }}$ May 2020 has dramatically continued to decline in the Year to Date (YTD). For instance, the Year to Date (YTD) performance on $1^{\text {st }}$ of October 2020 of KCB Group stood at $22.8 \%$, Equity Group Holding stood at 23.4\%, the Cooperative Bank of Kenya LTD stood at $18.0 \%$ while that of the Diamond Trust Bank Kenya Ltd stood at 15\%.

Moreover, the COVID 19 pandemic has put the banking sector in a situation of an elevated credit risk that is caused by the decline of their asset quality resulting from the increased number of Nonperforming loans as well as the provisions. A historically similar scenario was experienced in the year 1918 to 1920 when several financial institutions were faced with almost $80 \%$ of the total Nonperforming Loans in Europe during the period of the Spanish flu pandemic (Odhiambo, 2020).

Additionally, the issue of liquidity challenge continues to hit the banking sector in Kenya due to COVID 19 pandemic. This has been so since the interbank market has been faced with constraints of liquidity. Due to different measures taken by the government to help mitigate the impact of the pandemic to citizens, banking institutions have faced a lot of challenges in their attempt to manage and report on their position on liquidity and their capability in funding. Considering the regulatory demand that was put in place after 2008, the design of the regulations aimed at improving the banks' ability to meet the funding obligations through an establishment of liquidity buffer, and implementing a plan of contingency funding to guide the banking sector during times of crisis. However, in the current crisis of the COVID 19 pandemic, the liquidity tightening and operational challenges have put significant pressure on banking liquidity risk management (Liu, Manzoor, Wang, Zhang, \&Manzoor, 2020; Deloitte, 2020).

Given the challenges that banks are likely experiencing, organizations should take certain steps to address these challenges promptly to effectively manage current liquidity risk and better prepare for longer-term actions. First, the banks need to rapidly assess and take appropriate action on challenges related to liquidity and management requests such as in this time of financial market crisis the banks should preserve cash and access to liquidity in the banking overarching goal. Further, the banking institution management ought to ensure careful consideration is put in place to ensuring that ongoing and business-as-usual operational needs continue to be met while dealing with crisis-related issues. Further, other supplementary skilled and experienced resources may be required to provide additional capacity.

Moreover, for banks to remedy the liquidity risk, they are required to strengthen their liquidity monitoring and their capabilities of reporting. This would be possible through the banks' utilization of accurate and updated information in managing liquidity during the crisis as in this time of COVID 19 pandemic. Monitoring improvements should focus on currently available liquidity management tools, forecasts on expected and potential inflows and outflows, early warning indicators, and risk limits.

Further, looking at the banking risks associated with the workforce, the banking institutions should address the challenges through considerations of where employees will work, their feelings, and how management can lead them. The management should ensure working comfort to all the staff members through ensuring flexibility with work arrangement, setting up of risk mitigation programs for employees who may not be in a position to work on conferencing sites. Moreover, the banking sector should deploy mechanism to help employees to deal with stress that is likely to result due to different challenges brought by the COVID 19 pandemic. For instance, some employees may be dealing with medical issues, childcare challenges and disruption of family income. Thus it is appropriate for the banking sector to implement measures geared towards boosting e employees' morale.

\section{LITERATURE REVIEW}

COVID-19 being a global pandemic that has impacted the economic performance of several economic sectors including the banking sector, this literature review aims at evaluating the pandemic risk to business such as that of the banking sector through examining of other authors views that are analyzed through the adoption of different proposed technology related theories. The upcoming information technology has enormously impacted the growth and flexibility of user-friendly banking procedures 
(Nadim\& Begum, 2008). For the past few years, the electronic form of banking has highly been appreciated in the provision of the banking sector services mainly in online banking services in both local and foreign banks. The adoption of this technology has attracted smooth operations between interbank as well as in customer services.

\subsection{Theory of Reasoned Action}

The theory of Reasoned Action by (Fishbein\&Ajzen, 1975) stands as one of the popularly known theories used to explain the relationship between theory and action. The theory is about one factor that determines the behavioral intention of a person's attitudes towards a certain behavior. According to the two authors, behavior intentions were noted as a function of significant beliefs and facts concerning the likeliness of possessing a certain behavior that can lead to a particular outcome. According to the theory, , the behaviors that behold technology acceptance can be explained through the deployment of four main ideas which involve; intention to use and actual use, subjective norms, and lastly behavioral attitudes. The theory states that the costs of a certain behavior are evaluated by people who then formulate intentions to act that are in line with those evaluations. Based on (Ongare, 2013) study on longitudinal analysis of 44 commercial banks in Kenya and the resulting impact of electronic banking services provisions on perceived financial performance, the author found out that the individual behavior is determined by intentions as well as the subjective norms and the individual attitude determines the intention. The individual beliefs can be used to predict the individual attitude as well as the consequences of the resultant behavior, which according to the prediction chain.

\subsection{Pandemics and Their Effects on Business}

A pandemic impacts both supply and demand (Swift, 2009). The number of hours worked falls sharply due to illness and fear of infection, reducing aggregate supply. Lockdowns lead to lower retail sales and drastically reduced leisure activities (visits to sporting events, restaurants, theatres, etc.). Government interventions to halt the spread of a virus affects supply chains, which in turn impacts international trade. Previous studies examining the business effects of previous pandemics, and in particular, the effect on SMEs, are extremely limited. Typically, economic analysis of pandemics focuses on macroeconomic indicators, for example, GDP, rather than micro or firm-level effects. Predictions of the economic and social costs for a present-day pandemic are often based on the influenza pandemic of 1918 (termed 'Spanish Flu'1), (Garrett, 2007, 2008, 2009). In 2005, the World Bank suggested that a similar (current) influenza pandemic could cost the world economy $\$ 800$ billion and kill tens-of-millions of people, with long-run costs being much greater.

Literature examining the economic effects of the 1918 pandemic is based on printed media due to the lack of available economic data. Newspapers reviewed in Garrett $(2007,2008)$ suggest that firms in one US state saw their businesses decline by some 40 to 70 percent. Average business losses were more than $\$ 100,000$ per day (2006 prices). Many businesses, especially those in the service and entertainment industries, suffered double-digit losses in revenue. Other businesses that specialized in health-care products experienced an increase in revenues.

Mortalities reduced the supply of labor, increasing the marginal product of labor and capital per worker, in turn increasing real wages. Those US states that experienced a higher number of deaths per capita experienced higher rates of growth in per capita income following the pandemic. After the pandemic, the increase in capital per worker resulted in higher output per worker and higher incomes (Brainerd and Siegler, 2003). There were also implications for economic activity decades after the pandemic as pregnant women who were exposed to influenza in 1918 gave birth to children who had medical problems later in life, such as schizophrenia, diabetes, and stroke (Almond, 2006), reducing the future supply of labor and increasing future health-care costs. Reasonable inferences about the economic and social consequences of a modern-day pandemic can be made based on these 1918 pandemic effects. Deaths may be related to race, income, and place of residence, with higher mortality rates likely among densely populated areas within cities that are likely to have a higher number of low-income and ethnic-minority groups than suburban or more rural areas. Lockdowns and quarantines would hurt businesses in the short run. Some firms could lose a large proportion or all of their revenue (for example restaurants), whereas others could experience an increase in business (for example online-delivery firms). However, it seems unlikely given the nature of the mortality profile that the COVID-19 pandemic will result in labor shortages of the type present during the 1918 pandemic. 


\section{Methodology}

This paper used a qualitative approach where answers to questions why and how pandemics affect the banking sector were sought. The main source of data for the study was the existing secondary sources which included publications, internet sources, books and reports from various institutions such as the commercial banks and the international agencies.

The data was systematically reviewed and the findings presented based on the major observations from the data.

\subsection{Findings and Discussions}

\subsubsection{Historical Brief of the Pandemics and their effect on the Economy}

The main projected scenarios of pandemics are mild, moderate and severe as shown in the Table below. Linking these simulations with the previous pandemics, the first (mild) scenario is modeled on the Hong Kong flu of 1968-9; the moderate flu has the characteristics of the 1957 Asian flu; and the severe simulation is benchmarked on the 1918-9 Spanish flu(McKibbin\&Sidorenko 2006). Each of these scenarios assumes that efforts by individuals and official agencies to limit the spread of the disease are no more effectual than those observed during previous epidemics and reflects differences in population density, poverty, and the quality of healthcare available. For the world as a whole, a mild pandemic would reduce output by less than 1 percent of GDP, a moderate outbreak by more than 2 percent, and a severe pandemic by almost 5 percent, constituting a major global recession. Generally speaking, developing countries would be hardest hit, because higher population densities and poverty accentuate the economic impacts in some countries.

Table1. Projections of Economic Effects of a Pandemic

\begin{tabular}{|c|c|c|c|}
\hline (\% change in GDP, first-year) & $\underline{\text { Mild }}$ & Moderate & $\underline{\text { Severe }}$ \\
\hline World & -0.7 & -2.0 & $\overline{-4.8}$ \\
\hline High-income & -0.7 & -2.0 & -4.7 \\
\hline Developing & -0.6 & -2.1 & -5.3 \\
\hline East Asia & -0.8 & -3.5 & -8.7 \\
\hline Europe and Central Asia & -2.1 & -4.8 & -9.9 \\
\hline Middle-East \& North Africa & -0.7 & -2.8 & -7.0 \\
\hline South Asia & -0.6 & -2.1 & -4.9 \\
\hline Deaths (millions) & 1.4 & 14.2 & 71.1 \\
\hline
\end{tabular}

The projected decline in GDP including the costs of treatment and measures to control the infection is as shown in Table 2. The results show that based on previous pandemics, the World would lose over US\$1.5 trillion to the pandemic with the Sub-Saharan Africa losing over US\$26 billion. According to the World Bank (2006), the banking industry would be the worst hit in case of pandemic. This is because lesser people would concentrate on entrepreneurship and business thus minimal uptake of loans while loan servicing declines due to lose of jobs and other economic activities.

Table2. A breakdown of Economic impacts of a potential Human-to-Human Pandemic

\begin{tabular}{|c|c|c|c|c|c|}
\hline & \multicolumn{3}{|c|}{ Impact of: } & \multirow[b]{2}{*}{ Total } & \multirow[b]{2}{*}{ Total $^{\mathrm{d}}$} \\
\hline & Mortality $^{a}$ & $\begin{array}{c}\text { Illness and } \\
\text { Absenteeism }^{\text {b }}\end{array}$ & $\begin{array}{l}\text { Efforts to } \\
\text { avoid } \\
\text { infection }^{c}\end{array}$ & & \\
\hline & \multicolumn{4}{|c|}{$(\%$ of GDP $)$} & (\$ billion) \\
\hline World total & -0.4 & -0.9 & -1.9 & -3.1 & $-1,526$ \\
\hline High income countries & -0.3 & -0.9 & -1.8 & -3.0 & $-1,131$ \\
\hline Low and middle income countries & -0.6 & -0.9 & -2.1 & -3.6 & -405 \\
\hline East Asia and Pacific & -0.7 & -0.7 & -1.2 & -2.6 & -99 \\
\hline Europe and Central Asia & -0.4 & -0.7 & -2.3 & -3.4 & -83 \\
\hline Latin America and the Caribbean & -0.5 & -0.9 & -2.9 & -4.4 & -118 \\
\hline Middle East and North Africa & -0.7 & -1.2 & -1.8 & -3.7 & -25 \\
\hline South Asia & -0.6 & -0.8 & -2.2 & -3.6 & -37 \\
\hline Sub Saharan Africa & -0.6 & -0.9 & -2.2 & -3.7 & -26 \\
\hline
\end{tabular}




\subsection{Global Effects of COVID-19 on Banking Sector}

A report by the Price Water Coopers (PWC) (2020) revealed that the banking sectors in the USA is at the central of most of the measures undertaken to ease the members of the public from the COVID-19 pressure. The report highlighted the lowering of interest rates, the need for social distance, the push for lower transaction rates to encourage non-cash transactions and all these coupled with the decline in business and economic activities. While according to PWC the banks should reduce their branchesnetwork, some banks consider this as a concept that would give room to their competitors while others consider any recoup measures to be against their strategy and growth targets.

In Saudi Arabia, as reported by the KPMG-Saudi (2020), the fiscal measures undertaken by the government to ease the effects of COVID-19 on the people's livelihoods affected the banking sector adversely to the point of some banks recording monthly loses. The decline in the oil prices affected the countries financial capacity thus translating to low liquidity ratios among the banks. Among the measures that the government of Saudi Arabia took in relation to the banking sector included introduction of flexible repayment of financial dues owed by the members of the public to the commercial banks including loans and mortgages, waiver on the fees and other related charges associated with digital forms of banking as well as review of the credit card rates to a more reasonable amount. All these measures although they were meant to relieve the members of the public from the harms of COVID-19 including job loses, cost commercial banks huge sums of money.

The Banking Sector in China was also not left out of the hook by the COVID-19 Pandemic. As reported by the Diplomat, the banking sector in China especially the smaller banks have been facing huge performance and operational challenges since the onset of the Pandemic. China's Banking and Insurance Regulatory Committee reports that one of the main reasons as to why the performance of these banks has been affected is that one-third of the banks' lending went to manufacturing, wholesale and retail, and transportation, storage, and postal services, and these sectors are significantly distressed by the pandemic. With the challenges that have faced these sectors due to COVID-19, they translate to the issues in the commercial banks who highly depend on the industries for loan repayments. Secondly, over 75 percent of the banks' revenues come from interest income. As the central bank cut prime lending rates in February to stimulate the economy, it reduced the Net Interest Margin (NIM) of the banks and this leaves the banks as the main culprits of the pandemic.

The small and medium-sized banks in most of the developing countries account for a much larger share of the loans to small- and medium-sized enterprises (SMEs). While large commercial banks take up over 60 percent of the banking sector assets, they only account for around 30 percent of SME loans, whereas joint stock banks, urban commercial banks, and rural commercial banks comprise 70 percent of such loans. In particular, rural commercial banks account for 37.6 percent of SME loans. The quality of SME loans is quickly worsening as SME borrowers are hard hit during the pandemic. The industry-wide nonperforming loan (NPL) ratio for banks has climbed from 1.86 percent in the last quarter of 2019 to 2.04 percent in the first quarter of 2020.

\subsubsection{The Banking Sector in Kenya under COVID-19 Pandemic}

The reports in the Kenyan banking sector reveal that while most of the banks still record 'normal' business flows, this could not be the case especially among the small and medium-sized banks. While the banks are trying their best to sustain their business continuity and ensure a well-contained supply chain, the COVID-19 pandemic continues to affect many aspects of the banking industry. One of the major areas affected by the Pandemic is the SME sector. The SMEs according to Capital Markets Authority (CMA) are among the major borrowers in the commercial banks with over $86 \%$ of these enterprises obtaining their funding from Commercial Banks. On the same spot, since the onset of the COVID-19 pandemic, over 64\% of the SMEs in Kenya have either restrained from any borrowing or have reduced their commitment to servicing their loans. This is coupled by the government's emphasis to the commercial banks to extent/renegotiate the loan repayment terms as a way to give reprieve and relief Kenyans from the effects of COVID-19. The measures put in place to contain the spread of the pandemic such as restricted movement and curfews have impaired the operations of SMEs. This has, in turn, negatively impacted revenue streams for many. This poses a challenge to banks who have heavily lent to these businesses. When the affected SMEs cannot repay their loans, it impacts the bank's loan portfolio whose quality is dictated by the creditworthiness of the borrowers. 
The data available from the Central Bank of Kenya (CBK) reveal that the non-performing Loans (NPL) for the largest commercial banks in Kenya have steadily increased in the first and second quarters of the 2020 financial year. This signifies the effects of the pandemic to the banks where businesses and individuals are unable to repay their loans. Some sectors such as the tourism, Education, Religious and hotel industry have been almost completely shut. The employees and companies in this sector who had outstanding loans at the commercial banks have been unable to service their loans and this stretches the harm to the commercial banks. As shown in Figure 1, cooperative bank has seen a steady rise in the NPL ratio the same case to KCM and DTB.

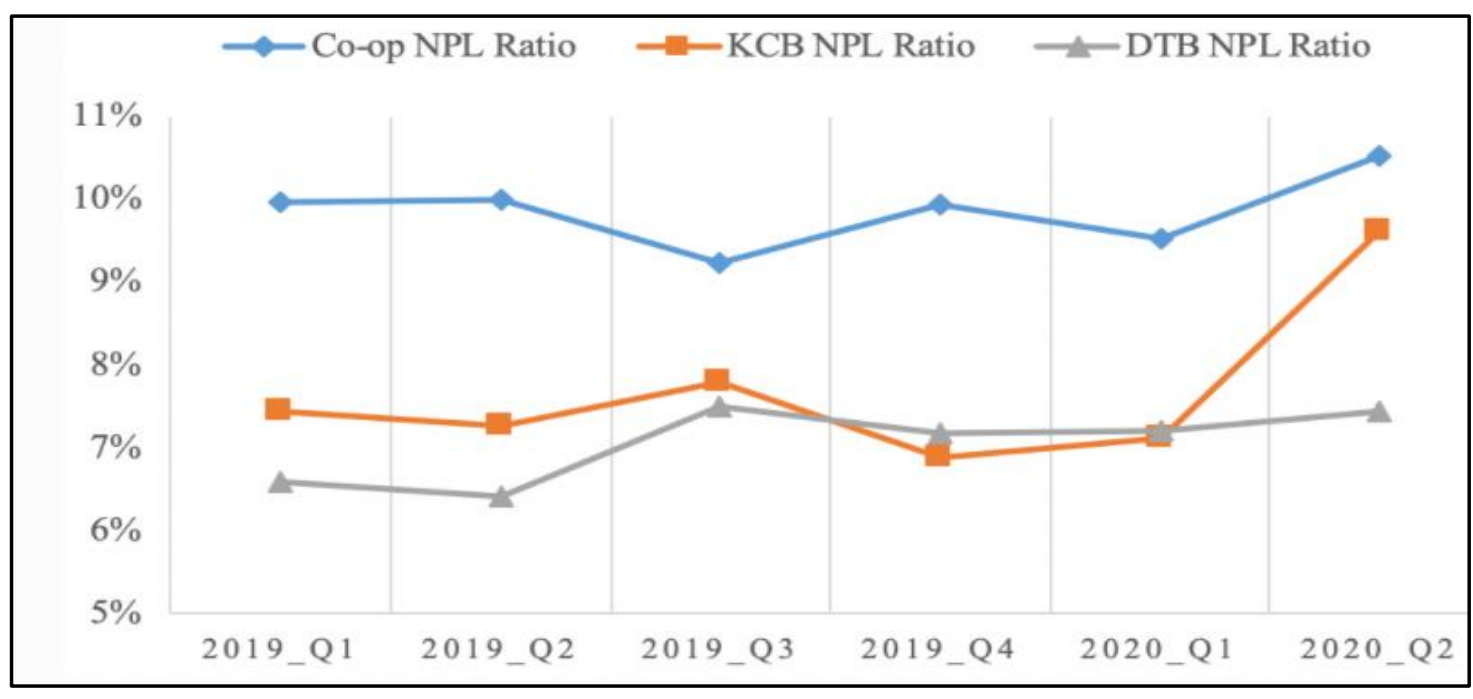

Figure1. Non-performing Loans

Source: $C B K(2020)$

The loan portfolio in the Kenyan commercial banks has also steadily reduced in the first and second quarters of the 2020 financial year. As shown in the Figure 2, the loan portfolio for Cooperative Bank declined to a record of $-2 \%$ in the second quarter of the financial 2020 while the loan portfolio for the Kenya Commercial Bank (KCB) declined to $0.3 \%$ and the loan portfolio for the DTB bank dropped $0.6 \%$ in the second quarter of the 2020 financial year. This implies a decline in the uptake of loans which depicts the scenario of declined business operations due to COVID-19 preventive measures.

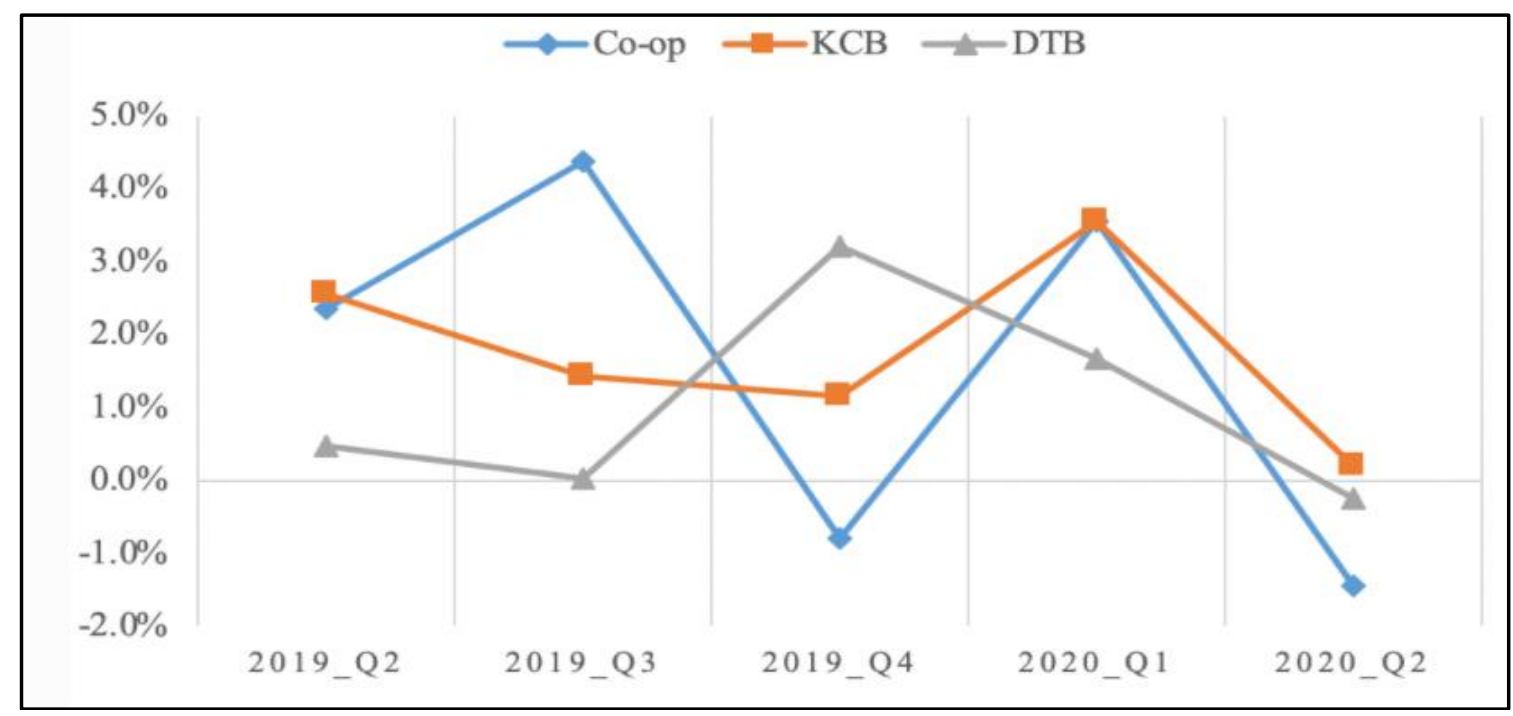

Source: $C B K(2020)$

To minimize the spread of the virus, the government has increasingly advocated for non-cash transactions among the citizens. As a way of facilitating this, the commercial banks brought measures including the increase in the limit of daily ATM withdrawals as well as minimization of mobile banking transaction rates. This implies that the commercial banks are losing billions of shillings out of their efforts to cushion their customers from the effects of the pandemic. 


\section{CONCLUSION AND RECOMMENDATIONS}

It is apparent that the Covid-19 pandemic has negatively impacted the performance of Commercial Banks in Kenya. The impact of this pandemic on commercial banks is evident from the reduction in top line revenues, increased operational costs occasioned by investments in new technologies to meet government requirement on customer interaction, increase in loan loss provisions resulting to elevated non-performing loans (NPLS) driven by inability of customers (both individuals and MSMEs) to service their obligations given loss of jobs, business operation shut down, and generally reduced economic activities.

Banks must re-evaluate their current strategy and re-align with the prevailing circumstances if they are to survive. The strategy must focus on what to do in the short term to ride the rough tide occasioned by the pandemic. Banks must re-orient their staff through re-skilling and re-tooling to empower them to face today's realities.

Banks ought to lobby for the regulators by the Central Bank to be temporarily relaxedespecially the stringent requirements such as liquidity thresholds, capital requirements and provisioning for loan losses to cushion the them during these turbulent times. This will ensure that the banks are able to smoothly operate without causing further retrenchment measures such as redundancies and closure of branches.

In Conclusion, the COVID-19 pandemic is hard-hitting the world economy and the financial institutions such as the commercial banks are not spared. As the governments take containment measures such as lockdowns and offering financial incentives to the public, the commercial banks have to brace-off for a more tough time ahead. The banks, therefore, ought to come up with measures and strategies to ensure their operations and markets as well as their financial value are protected to avoid further decline and effect on their future sustainability. The focus should majorly be on the fragile and vulnerable product lines that show instability in market even during the normal economic periods and those that are more prone to competition.

\section{REFERENCES}

[1] Almond, D. (2006). Is the 1918 influenza pandemic over? Long-term effect of in utero influenza exposure in the post-1940 U.S. population. Journal of Political Economy, 114, 4, 672-712.

[2] Ashraf, B. N. (2020). Stock markets' reaction to COVID-19: cases or fatalities?. Research in International Business and Finance, 101249.

[3] Brainerd, E. and Siegler, M. (2003). The economic effect of the 1918 Influenza Epidemic. Centre for Economic Policy Research. Discussion Paper No: 3791

[4] Deloitte. (2020). COVID-19 impact on bank liquidity risk management and response

[5] Garrett, T. A. (2007). Economic effects of the 1918 influenza pandemic: Implications for a modern-day pandemic. Federal Reserve Bank of St. Louis. https://www.stlouisfed.org/ /media/files/pdfs/communitydevelopment/researchreports/pandemic_flu_report.pdf

[6] Garrett, T. A. (2008). Pandemic economics: The 1918 influenza and its modern-day implications. Federal Reserve Bank of St. Louis Review, 90.

[7] Garrett, T. A. (2009). War and pestilence as labor market shocks: US manufacturing wage growth 19141919. Economic Inquiry, 47, 711-725

[8] Karungu, R., Memba, F., \&Muturi, W. (2020). Influence of financial contagion on stock performance of firms listed in the Nairobi securities exchange. Accounting, 6 (1), 1-16.

[9] Liu, H., Manzoor, A., Wang, C., Zhang, L., \&Manzoor, Z. (2020). The COVID-19 outbreak and affected countries stock markets response. International Journal of Environmental Research and Public Health, $17(8), 2800$.

[10] Odhiambo, J., Weke, P., \&Wendo, J. (2020b). Modeling of Returns of Nairobi Securities Exchange 20 Share Index Using Log-Normal Distribution.

[11] Ogare, H.O (2013). The effect of electronic banking on the financial performance of commercial banks in Kenya. Unpublished MBA project. Nairobi: University of Nairobi.

[12] Ozili, P. K., \&Arun, T. (2020). Spillover of COVID-19: impact on the Global Economy. Available at SSRN 3562570.

[13] Swift, K. T. (2009). Economic effects of a flu pandemic. Chemical Engineering Progress, 105, 9, p.22. 
Are Pandemics A Threat To Businesses? Lessons from Covid-19 Pandemic; a Case of Banking Sector in Kenya

[14] Topcu, M., \&Gulal, O. S. (2020). The impact of COVID-19 on emerging stock markets. Finance Research Letters, 36, 101691.

[15] Wanjala, K. (2020). The Economic Impact Assessment of the Novel Coronavirus on Tourism and Trade in Kenya: Lessons from Preceding Epidemics. Finance \& Economics Review, 2(1), 1-10.

[16] World Bank. (2020). Global Economic Outlook During Covid-19 Pandemic. Retrieved from: https://www.worldbank.org/en/news/feature/2020/06/08/the-global-economic-outlook-during-the-covid19-pandemic-a-changed-world

[17] Zhang, D., Hu, M., \&Ji, Q. (2020). Financial markets under the global pandemic of COVID-19. Finance Research Letters, 101528.

Citation: Samuel Machiri Ndungu. "Are Pandemics A Threat To Businesses? Lessons from Covid-19 Pandemic; a Case of Banking Sector in Kenya" International Journal of Managerial Studies and Research (IJMSR), vol 9, no. 2, 2021, pp. 01-10. doi: https://doi.org/10.20431/2349-0349.0902001.

Copyright: (c) 2021 Authors. This is an open-access article distributed under the terms of the Creative Commons Attribution License, which permits unrestricted use, distribution, and reproduction in any medium, provided the original author and source are credited. 